Diabetologia 7, 328-333 (1971)

(C) by Springer-Verlag 1971

\title{
Effect of a High-Fat Diet on Obese-Hyperglycaemic and Non-Obese Bar Harbor Mice
}

\author{
D. Lemonnier, J. Winand, J. Fornetle and J. Christophe
}

Laboratoire de Biologie du C.N.A.M. et de Nutrition Humaine de l'I.N.S.E.R.M., Paris, France, and Department of Biochemistry and Nutrition, Brussels University School of Medicine, Brussels, Belgium

Received: February 23, 1971, aceepted: July 22, 1971

Summary. Dietary obesity induced by a high-fat diet was superimposed in mice already suffering from the hereditary obese-hyperglycaemic (O-H) syndrome. Sixweekold animals given a diet containing $41.5 \%$ lard for 4.5 months gained $150 \%$ more weight than those given a control $78.3 \%$ wheat flour diet. There was only a slightly significant difference in weight gain of the lean littermates given the same two diets. - The interaction of the high-fat diet and the ob/ob genotype led to a further enlargement of adipose cells and an increased number of mast cells in epididymal fat. Diabetes was not aggravated in spite of a reduction in the levels of serum insulin, and in the insulin content of the pancreas. -

The contribution of lipogenesis and dietary fat to the development of this obesity of mixed origin was estimated from an analysis of the fatty acid distribution in the diet, in three fat pads (epididymal, perirenal and subcutaneous), and in the liver. From the linoleate contents, it follows that fat depot in $\mathrm{O}-\mathrm{H}$ mice on a high-fat diet was made up of 4 times more exogenous fatty acids than endogenous acids, but in spite of this, net lipogenesis was hardly affected. Therefore, obese-hyperglycaemic mice have a tremendous capacity to deposit and retain any kind of fat. The fatty acid spectrum also indicates that a large portion of the dietary supply of palmitate and stearate was converted into palmitoleate and oleate.

Effets d'un régime riche en lipides sur les souris obèses. hyperglycémiques de Bar Harbor et leurs contróles nonobèses.

Résumé. Une obésité nutritionnelle est imposée à des souris souffrant déjà du syndrome congénital obésitéhyperglycémie $(\mathrm{O}-\mathrm{H})$. Des animaux de 6 semaines qui reçoivent un régime contenant $41.5 \%$ de lard pendant 4.5 mois subissent un gain pondéral dépassant de $150 \%$ celui observé avec un régime à base de $78.3 \%$ de farine. Chez les souris non-obèses la différence de poids provoquée par les deux régimes est à peine significative. - L'interaction du régime gras et du génotype ob/ob accentue l'hypertrophie des adipocytes et augmente le nombre des mastocytes dans la graisse épididymaire. Le diabète n'est pas aggravé malgré une réduction de l'insulinémie et du contenu pancréatique en insuline. - La contribution de la lipogenèse et du lard consommé au développement de cette obésité mixte peut êtro appréciée en analysant la distribution des acides gras dans le régime, dans trois pannicules adipeux (épididymaire, périrénal et souscutané) et dans le foie. Le contenu en linoléete indique que la graisse déposée par la souris $\mathrm{O}-\mathrm{H}$ au régime gras contiont 4 fois plus d'acides gras exogènes que d'acides gras endogènes et que la lipogenèse nette n'est guère réduite. La souris $\mathrm{O}-\mathrm{H}$ a donc une aptitude exceptionnelle à déposer et à retenir de la graisse, quelle que soit l'origine de cette dernière. Une proportion importante du palmitate et du stéarate ingérés est convertie par ailleurs en palmitoléate et oléate.

Einfluß einer fettreichen Diät auf fettsüchtig-hyperglykämische und nicht-fettsüchtige Bar Harbor Mäuse

Zusammenfassung. Fettsucht, die durch fettreiche Kost induziert wird, trat bei genetisch fettsïchtigen und hyperglykämischen Mäusen (O-H) in verstärktem Maße auf. Sechs Wochen alte Tiere erhielten eine Diät mit einem Fettgehalt von $41.5 \%$. Nach $41 / 2$ Monaten lag das Körpergewicht um 150\% höher als bei der Kontrollgruppe, die eine Diät mit einem Kohlenhydratanteil von $78.3 \%$ bekommen hatte. Das Körpergewicht nicht fettsüchtiger Kontrolltiere zeigte nach Vorbehandlung mit beiden Diäten nur geringgradige Unterschiede. Das Zusammentreffen diätetisch induzierter und genetisch determinierter Fettsucht führte zu weiterer Zellvergrößerung und zunehmender Zahl der Mastzellen im epididymalen Fettanhang. Obgleich die Seruminsulinspiegel und der Pankreasinsulingehalt abnahmen, trat keine Verschlechterung der diabetischen Stoffwechsellage auf. Der Anteil von Lipogenese und exogener Fettzufuhr an der Entwicklung dieser Fettsuchtsform wurde durch Analysen der Fettsäuren in der Diät, des epididymalen, perirenalen und subkutanen Fettgewebes und der Leber geschätzt. Aus dem Gehalt an Linolsäure läßt sich schließen, daß das Fettdepot von O-H Mäusen nach fettreicher Diät eine vierfach größere Menge exogener als endogener Fettsëuren enthält und die Nettolipogenese kaum reduziert ist. Genetisch fettsüchtige und hyperglykämische Mäuse haben demnach eine außerordentlich hohe Kapazität Fett zu speichern. Das Fettsäurespektrum zeigt weiterhin, daß ein großer Anteil der mit der Nahrung zugoführten Palmitinsäure und Stearinsäure in Palmito-oleinsäure und Oleinsäure überführt wird.

Key-words: Obese-hyperglycaemic mice, high-fat diet, dietary obesity, adipose tissue, liver, fatty acids.

\section{Introduction}

A high-fat diet and hereditary predisposition may lead to obesity by various mechanisms.

Dietary obesity is induced under proper conditions by a high-fat diet in rats and mice fed ad libitum. This type of obesity is accompanied by an elevated thermochemical efficiency of growth (defined as the ratio between weight increase to caloric intake), with females accumulating more fat than males $[13,14,17$, $18,22]$. The number of fat cells remains normal in the epididymal fat pads of rats [16]. Each fat cell is hypertrophied [16], but the levels of RNA and TPNH. generating enzymes are low [7]. Lipogenesis is depressed in adipose tissue and liver $[4,8,12]$. Adipose tissue and muscle are insensitive to insulin in vitro $[2,21]$, 
and the rate of glucose utilization in vivo is depressed $[4,13]$. The secretory activity of $\beta$-cells is low $[1,2,21]$. Hepatic gluconeogenesis from protein is probably stimulated by a direct effect of the dietary fatty acids and by a secondary hypercorticism [15].

The autosomal recessive obesity of obese-hyper. glycaemic $(\mathrm{O}-\mathrm{H})$ mice is quite different. This spontaneous obesity is due to the presence of ob gene in linkage group XI. The syndrome is characterized by a high degree of hyperinsulinism [3]. The fat accumulated in 2-months-old $\mathrm{O}-\mathrm{H}$ mice maintained on a standard diet is poor in $18: 2$. Moreover, the glycerides stored by adipose cells are rich in 16:1 and those present in the fatty liver contain an excess of $16: 1$ and 18:1 [26]. Two factors account for the quantitative and qualitative aspects of this endogenous obesity:

1. Lipogenesis is very active and the contribution of the liver to adipose tissue glycerides is more important in $\mathrm{O}-\mathrm{II}$ mice than in their lean littermates;

2. The enhanced activity of the particulate enzymes monodesaturating and elongating acyl-CoA is due to their induction by insulin [26].

It was thought of interest to see whether $\mathrm{O}-\mathrm{H}$ mice fed on a high-fat diet could be differentiated from $\mathrm{O}-\mathrm{H}$ mice maintained on a high-carbohydrate diet and from their lean littermates raised on the same diets. The purpose of this paper was to investigate whether obesity could be aggravated when hereditary and dietary factors were acting simultaneously, and also how the quality of the stored fat was influenced.

\section{Materials and Methods}

Ten obese-hyperglycaemic (ob/ob) male animals and 10 lean littermates $\left(\mathrm{ob} / \mathrm{ob}^{+}\right.$or $\left.\mathrm{ob}^{+} / \mathrm{ob}^{+}\right)$of the same sex were obtained from a colony of mice from the original stock $\mathrm{V}$ of Bar Harbor (Maine, U.S.A.) raised by the Centre de Sélection et d'Elevage des animaux de laboratoire of the Centre National de la Recherche Scientifique (Orléans - La Source, France). These mice, previously maintained on a standard diet, were divided into 2 groups when 6 weeks old, each having the same mean body weight ( $42 \mathrm{~g}$ for $\mathrm{O}-\mathrm{H}$ mice and $28 \mathrm{~g}$ for control mice). Once distributed, the animals were fed ad libitum either a high-carbohydrate diet or a high-fat diet with the same protein content, until killing.

The composition of the high-carbohydrate diet consisted of the following (in $\%, w / w$ ): wheat flour, 78.3 ; casein, 12.1 ; DL-methionine, 0.4 ; salt mixture USP XIV, 4 ; bran, 3 ; vitamin mix, 2.2 ; the caloric source being $71 \%$ as carbohydrate, $7 \%$ as fat and $22 \%$ as protein. The vitamin supplements in $100 \mathrm{~g}$ of diet were: thiamine $1.5 \mathrm{mg}$; riboflavin $1.5 \mathrm{mg}$; pyridoxine $1 \mathrm{mg}$; calcium pantothenate $5 \mathrm{mg}$; niacin $5 \mathrm{mg}$; vitamin $\mathrm{B}_{12} 5 \mu \mathrm{g}$; biotin $0.1 \mathrm{mg}$; choline chloride $200 \mathrm{mg}$; inositol $50 \mathrm{mg}$; $p$-aminobenzoic acid $30 \mathrm{mg}$; vitamin A 800 I.U.; vitamin $\mathrm{D}_{3} 200$ I.U.; vitamin $\mathrm{E}$
$30 \mathrm{mg}$; menadione $1 \mathrm{mg}$; polyunsaturated fatty acids $280 \mathrm{mg}$.

The low carbohydrate, high-fat diet was as follows: wheat flour, 7.6 ; casein, 30.0 ; salt mixture USP XIV, 6 ; lard, 41.5; bran, 4.5 ; vitamin mix, 3.3 ; the caloric source being $5 \%$ as carbohydrate, $74 \%$ as fat and $22 \%$ as protein. As shown in Table 3, approximately $50 \%$ of the fatty acids present in the high-lard diet were saturated and the proportion of 18:2 was low (9\%). The lipids accompanying the high-carbohydrate diet were rich in $18: 2(33 \%)$.

After 4.5 months on these 2 diets (i.e. at the age of 6 months), all animals were killed by decapitation between 10.30 A.M. and 12.30 P.M. The serum was collected by centrifugation and stored at $-30^{\circ} \mathrm{C}$ until analyzed for glucose with a glucose oxidase kit (Biotrol, Paris, France) and for insulin with the Sorin-Cea double antibody kit (Commissariat à l'Energie Atom. ique, Gif-sur-Yvette, France). The insulin immunoassays were conducted on sera adequately diluted with $1 \%$ buffered bovine albumin. A rat insulin standard was a $5 \times$ crystalline preparation obtained. through the courtesy of Dr. H. Ege (Novo Research. Institute, Copenhagen, Denmark). The whole pancreas was carefully dissected, weighed and rapidly homogenized in acid-alcohol. After centrifugation, aliquots of the supernatants were diluted in $1 \%$ buffered bovine albumin for insulin assay [20]. Samples from the liver and the gastroonemius of the hind leg were extracted in $\mathrm{KOH}(30 \%, \mathrm{w} / \mathrm{v})$ for assay of their glycogen [20].

Three pairs of fat pads were weighed: epididymal, perirenal and subcutaneous (from the hip region). Fragments of the epididymal fat pads were fixed, embedded, sectioned, and examined as previously described $[16,17]$.

The lipids of adipose tissue and liver were studied on 6 animals. The pooled samples were extracted with chloroform-methanol (2:1). Liver lipids were fractionated by thin-layer chromatography into neutral lipids and free fatty acids, and into total phospholipids. The gas-chromatography of the fatty acid methylesters was conducted on Apiezon $L$ as previously described [26]. The interrelations of fatty acids were estimated from their \% distribution with the following four criteria. The mono-desaturation index of $16: 0$ was calculated as $16: 1 / 16: 0+16: 1$, the mono-desaturation index of $18: 0$ as $18: 1 / 18: 0+$ $18: 1$, the elongation index of $16: 0$ as $18: 0+18: 1$ / $16: 0+16: 1+18: 0+18: 1$, and the contribution of dietary lipids as $18: 2 / 16: 0$.

\section{Results}

\section{A. General parameters}

1. Comparison of 6 months old $O_{-} H$ mice fed on $a$ high-carbohydrate diet with their lean littermates.

Obese-hyperglycaemic mice were almost twice as heavy as lean littermates (Table 1). Subcutaneous and 
perirenal fat pads were 6 - to 7 -fold larger than normal. The enlargment of epididymal fat pads was twofold and also significant $(p<0.01)$. The histological examination of sections of this perigenital fat reveals that the number of adipose cells per fat pad was not increased, but that the size of these cells was about three times as large as that in the nonobese (Table 2). There was no sign of fat cell degeneration. The proportion of mast cells present among fat cells was twice that observed in the control fat pad. The weight of the liver was increased, although there was no liver hypertrophy on a relative basis (Table 1). Liver glycogen was normal on a wet weight basis, but increased per organ. The glycogen content of the gastrocnemius was significantly elevated $(p<0.05)$ on a wet weight basis. Hypersecretion of the $\beta$-cells was characterized by very high levels of serum insulin (41 times the control value) and a normal insulin content of the pancreas (i.e. decreased stored insulin/ $100 \mathrm{~g}$ body weight). The serum glucose was increased two-fold.

\section{Effects of a high-fat diet on lean littermates and $\mathrm{O}-\mathrm{H}$ mice.}

The administration of a diet containing $41.5 \%$ lard for 4.5 months resulted in a moderate $(+11 \%)$ but significant increase of body weight in lean mice and was accompanied by increased deposition in epididymal and perirenal fat pads (Table 1). The slight hypertrophy of subcutaneous fat was not significant. In epididymal fat pads there was an hypertrophy of adipose cells but no hyperplasia (Table 2 ). There is no apparent explanation for the significant elevation of serum insulin.

In $\mathrm{O}-\mathrm{H}$ mice, the high-fat diet led to a spectacular $50 \%$ increase in body weight. In these animals, it can be estimated, by comparison with the weight of lean littermates, and knowing that the fat-free body weight is not increased [11], that fat represented over $50 \%$ of the body weight. The increase in the weight of perirenal $(+211 \%)$ and subcutaneous fat pads $(+130 \%)$ was more important than that of epididy. mal fat $(+51 \%)$. A further enlargement of adipose cells was sufficient to account for the hypertrophy of epididymal fat (Table 2). The liver did not participate in this increase in body weight, and its contribution decreased therefore on a proportional basis (Table 1). Glycogen concentration was unaffected in the liver but depressed in the gastrocnemius by the high-fat diet. Diabetes was not aggravated in spite of the reduction in the levels of serum insulin, and insulin stored in the pancreas.

B. Comparison of fatty acid distribution in three fat pads of 6 months old $O-H$ mice, fed on a high-carbohydrate or a high-lard diet, with lean littermates raised on the same diets.

The fatty acid distribution of epididymal, subcutaneous and perirenal fat pads was comparable in each type of mice (i.e. was independant of their anatomical situation) (Table 3 ). That adipose tissue obtained from different sites has similar fatty acid content has already been observed in rats [6] and men [10].

In general, the fat stored in adipose cells of $\mathrm{O}-\mathrm{H}$ mice on the high-carbohydrate diet, when compared with that of lean littermates, showed a slight decrease in the relative contents of $16: 0,16: 1$ and $18: 0$, whereas 18:2 was normal and 18:1 elevated by approximately $20 \%$ (Table 3 ). The four indices in Table 3 suggest that these variations were mostly due to a $20 \%$ improvement in the elongation of $16: 0$.

In lean mice on the high-fat diet, the proportions of $16: 1$ and $18: 2$ were halved and that of $16: 0$ decreased by $20 \%$, whereas those of $18: 0$ and $18: 1$ showed a marked increase in the three fat pads (Table 3 ). The four indices (Table 3) indicate a reduction in the mono-desaturation of $16: 0$ and in the $18: 2$ content, and a better elongation of $16: 0(+40 \%)$.

In $\mathrm{O}-\mathrm{H}$ mice, these qualitative variations were quite comparable with those abserved in the lean littermates (Table 3).

C. Comparison of fatty acid distribution in liver lipids of 6-month old $O-H$ mice fed on a highcarbohydrate or a high-lard diet with lean littermates raised on the same diets.

In $\mathrm{O}-\mathrm{H}$ mice, neutral lipids (glycerides and free fatty acids) contained more $16: 0$ and less $18: 2$, when compared with lean littermates (Table 4). The monodesaturation of $18: 0$ and the elongation of $16: 0$ were slightly elevated. There was very little difference in total phospholipids between $\mathrm{O}-\mathrm{H}$ mice and lean littermates, apart from a greater 18:0/18:1 ratio in obese animals.

The high-fat diet had similar effects on the fatty acid distribution in the liver lipids of both groups of mice. In neutral lipids, the $16: 0 / 16: 1$ ratio increased and the proportion of $18: 2$ behaved similarly. In phospholipids, the mono-unsaturated fatty acids were decreased. The general composition of these lipids was reminiscent of the lard consumed, the only obvious difference being a better desaturation of $16: 0$ in the liver.

\section{Discussion}

\section{A. Lean littermates on a high-fat diet}

The tendency towards obesity displayed on a highfat diet was less striking in Bar-Harbor nonobese mice than in Swiss albino mice and in rats on similar diets (Lemonnier, to be published, and ref. 13, 14, 17, 22). The variations in fatty acid distribution made the fat stored by lean Bar-Harbor mice somewhat similar to the lard consumed. However, the composition of the dietary fat was altered by an increased elongation of fatty acids. This has also been observed in rats on a 
Table 1. Effects of a high-fat diet on 6-month old lean and obese-hyperglycaemic male mice. The animals were maintained for 4.5 months on a $41.5 \%$ lard diet and were compared with controts maintained on a high carbohydrate diet. Values are mean $\pm S . E . M$.

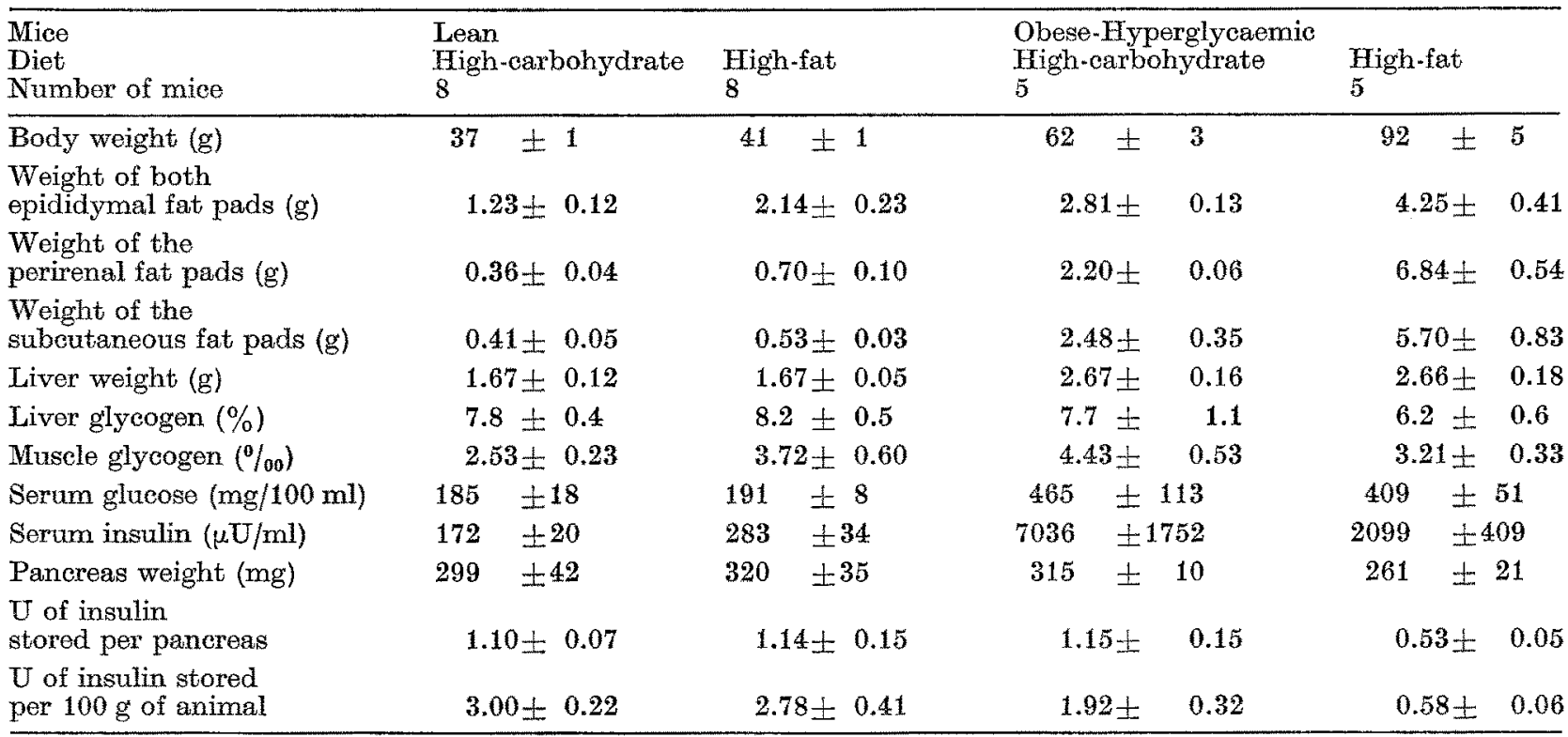

Table 2. Comparative effecte of a high-carbohydrate diet and a high-fat diet on the size and number of adipose cells, and on the number of mast cells in epididlymal fat pads. Values are mean \pm S.E.M.

\begin{tabular}{lccccc}
\hline $\begin{array}{l}\text { Mice } \\
\text { Diet } \\
\text { Number of mice }\end{array}$ & $\begin{array}{l}\text { Lean } \\
\text { High-carbohydrate } \\
5\end{array}$ & $\begin{array}{l}\text { High-fat } \\
5\end{array}$ & \multicolumn{2}{c}{$\begin{array}{l}\text { Obese-Hyperglycaemic } \\
\text { High-carbohydrate }\end{array}$} & $\begin{array}{l}\text { High-fat } \\
5\end{array}$ \\
\hline $\begin{array}{l}\text { Weight of both } \\
\text { epididymal fat pads }(\mathrm{g})\end{array}$ & $\mathbf{1 . 2 3 \pm 0 . 1 3}$ & $2.28 \pm 0.31$ & $2.81 \pm 0.13$ & $4.26 \pm 0.41$ \\
$\begin{array}{l}\text { Adipose cell } \\
\text { volume }\left(\times 10^{3} \mu^{3}\right)\end{array}$ & $321 \pm 43$ & $680 \quad \pm 55$ & 908 & \pm 70 & 1179 \\
$\begin{array}{l}\text { Total number of } \\
\text { adipose cells }\left(\times 10^{6}\right)\end{array}$ & $4.28 \pm 0.17$ & $3.61 \pm 0.25$ & $3.46 \pm 0.25$ & $4.05 \pm 0.44$ \\
$\begin{array}{l}\text { Number of mast cells } \\
\text { per thousand adipose cells }\end{array}$ & $1.62 \pm 0.38$ & $1.88 \pm 0.11$ & $3.20 \pm 1.26$ & $5.13 \pm 1.62$ \\
\hline
\end{tabular}

Table 3. Effects of a high-fat diet on the \% distribution of fatty acids in the lipids of three different fat pads of 6 lean and 6 obese-hyperglycaemic mice ( $E P=$ epididymal fat; $S-C=$ subcutaneous; $P-R=$ perirenal). The \% distribution of fatty acids in the lipids of both diets are indicated for comparison. The contribution of each fatty acid was estimated from a total $(100 \%)$ including all fatty acids ranging from $10: 0$ to $22: 0$

\begin{tabular}{|c|c|c|c|c|c|c|c|c|c|c|c|c|c|c|}
\hline \multirow{3}{*}{$\begin{array}{l}\text { Mice } \\
\text { Diet } \\
\text { Fat pad }\end{array}$} & \multicolumn{6}{|l|}{ Lean } & \multicolumn{6}{|c|}{ Obese-Hyperglycaemie } & \multicolumn{2}{|c|}{ Dietary lipids } \\
\hline & \multicolumn{3}{|c|}{ High-carbohydrate } & \multicolumn{3}{|c|}{ High-fat } & \multicolumn{3}{|c|}{ High-carbohydrate } & \multicolumn{2}{|c|}{ High-fat } & \multirow[b]{2}{*}{ P-R } & \multirow{2}{*}{$\begin{array}{l}\text { High } \\
\text { carbo- } \\
\text { hydrate }\end{array}$} & \multirow{2}{*}{$\begin{array}{l}\text { High } \\
\text { fat }\end{array}$} \\
\hline & & $\mathrm{S}-\mathrm{C}$ & P.R & $\mathrm{EP}$ & $\mathrm{S}-\mathrm{C}$ & P.R & EP & $\mathrm{S}-\mathrm{C}$ & P-R & $\mathrm{EP}$ & S-C & & & \\
\hline Fatty acid & & & & & & & & & & & & & & \\
\hline $14: 0$ & 1.7 & 1.8 & 1.4 & 0.8 & 0.9 & 0.8 & 1.0 & 1.1 & 1.3 & 0.7 & 0.6 & 0.8 & 0.8 & 1.5 \\
\hline $16: 0$ & 27.6 & 25.4 & 25.8 & 19.4 & 20.2 & 20.3 & 23.2 & 21.8 & 22.5 & 20.1 & 18.8 & 20.9 & 22.5 & 25.8 \\
\hline $16: 1$ & 11.5 & 15.4 & 11.5 & 5.0 & 5.6 & 4.7 & 10.1 & 9.8 & 10.8 & 5.2 & 5.5 & 6.4 & 1.3 & 2.6 \\
\hline $18: 0$ & 2.4 & 2.4 & 2.1 & 4.1 & 4.1 & 5.5 & 1.9 & 1.6 & 2.5 & 4.4 & 3.9 & 3.4 & 9.0 & 15.7 \\
\hline $18: 1$ & 39.7 & 39,3 & 37.9 & 60.4 & 59.4 & 59.8 & 45.6 & 48.2 & 46.1 & 58.4 & 61.9 & 55.8 & 31.6 & 37.6 \\
\hline $18: 2$ & 14.1 & 12.4 & 15.3 & 7.8 & 6.5 & 6.2 & 14.1 & 14.8 & 13.8 & 7.5 & 7.2 & 8.2 & 33.3 & 9.3 \\
\hline Index & & & & & & & & & & & & & & \\
\hline $\begin{array}{l}\text { Mono-desaturation } \\
\text { of } 16: 0\end{array}$ & 90 & 38 & 31 & 90 & 99 & 10 & 30 & 31 & 29 & 9 & 98 & 3 & 6 & 9 \\
\hline Mono-desaturation & & & & & & & & & & & & & & \\
\hline of $18: 0$ & 94 & 94 & 95 & 94 & 94 & 92 & 96 & 97 & 95 & 93 & 94 & 94 & 78 & 70 \\
\hline Elongation of $16: 0$ & 52 & 50 & 52 & 73 & 71 & 72 & 59 & 61 & 59 & 71 & 73 & 69 & 63 & 65 \\
\hline $18: 2 / 16$ & 51 & 49 & 59 & 40 & 32 & 30 & 61. & 68 & 61 & 37 & 38 & 39 & 148 & 36 \\
\hline
\end{tabular}


high-fat diet [24]. The increased proportion of $18: 2$ observed in liver neutral lipids, in the face of a diet poor in $18: 2$, probably resulted from reduced hepatic lipogenesis. simultaneously. These results clearly confirm that in general, obesity and hyperinsulinism are not necessarily associated [21]. At the tissue level, it has already been demonstrated that adipose tissue $[5,11,19]$ and

Table 4. Effects of a high-fat diet (H-F) on the \% distribution of fatty acids in the liver lipids of 6 lean and 6 obese-hyperglycaemic mice. The $41.5 \%$ lard diet was compared with a high-carbohydrate diet $H$-C. Neutral lipids are all liver lipids minus phospholipids and their fatty acid content corre. sponds mostly to triglycerides

\begin{tabular}{|c|c|c|c|c|c|c|c|c|}
\hline Lipids & Neut & lipids & & & Phos & olipids & & \\
\hline Mice & lean & & $\mathrm{O}-\mathrm{H}$ & & lean & & $\mathrm{O}-\mathrm{H}$ & \\
\hline Diet & $\mathrm{H}-\mathrm{C}$ & H-F & $\mathrm{H}-\mathrm{C}$ & H-F & $\mathrm{H}-\mathrm{C}$ & $\mathrm{H}-\mathrm{F}$ & $\mathrm{H}-\mathrm{C}$ & $\mathrm{H}-\mathrm{F}$ \\
\hline Fatty acid & & & & & & & & \\
\hline $14: 0$ & 1.4 & 0.7 & 0.9 & 0.5 & 1.4 & 0.1 & 0.2 & 0.1 \\
\hline $16: 0$ & 21.9 & 27.2 & 29.6 & 29.5 & 30.6 & 31.9 & 31.8 & 35.9 \\
\hline $16: 1$ & 7.5 & 2.3 & 6.1 & 3.0 & 2.8 & 0.8 & 2.2 & 0.9 \\
\hline $18: 0$ & 3.5 & 3.4 & 2.2 & 3.1 & 22.2 & 30.3 & 33.7 & 44.3 \\
\hline $18: 1$ & 26.1 & 38.4 & 49.0 & 45.6 & 33.3 & 15.9 & 17.4 & 11.9 \\
\hline $18: 2$ & 8.8 & 11.8 & 4.0 & 9.7 & 7.4 & 13.0 & 9.6 & 5.6 \\
\hline Index & & & & & & & & \\
\hline mono-c & 25 & 8 & 17 & 9 & 8 & 2 & 6 & 2 \\
\hline mono-desaturation of $18: 0$ & 88 & 92 & 96 & 94 & 60 & 34 & 34 & 21 \\
\hline elongation of $16: 0$ & 50 & 59 & 59 & 60 & 62 & 59 & 60 & 60 \\
\hline $18: 2 / 16: 0$ & 40 & 43 & 13 & 33 & 24 & 41 & 30 & 16 \\
\hline
\end{tabular}

\section{B. Obese-hyperglycaemic mice on the standard diet}

The age at killing corresponded probably to the period of maximum hyperinsulinism (Table 1 and ref. 25). The distribution of non-essential fatty acids obtained here in Paris, in the adipose tissues and liver glycerides of 6 -months-old $\mathrm{O}-\mathrm{H}$ mice, fed a highcarbohydrate diet, can be compared with the data previously obtained on 2-month-old $\mathrm{O}-\mathrm{H}$ animals fed a stock diet in Bar-Harbor [26]. The main difference appears to be a higher proportion of $18: 1$ in adult mice contrasting with an excess of $16: 1$ in the young animals previously studied. This shift among the mono-unsaturated fatty acids in $\mathrm{O}-\mathrm{H}$ mice could be due to ageing and/or to the diet. The elevated $18: 2 / 16: 0$ ratio, compared with the same ratio in lean littermates, suggests a decreasing capacity of adipose tissue for lipogenesis in ageing mice. This would confirm the effect of age observed in vitro $[4,5]$ and in vivo [11], when labelled precursors are metabolized by adipose tissue. On the other hand, the low $18: 2 / 16: 0$ ratio in liver neutral lipids suggests that a high lipogenetic activity was maintained in this organ, when compared with 6-month old lean littermates.

\section{fat diet.}

C. Obese-hyperglycaemic mice maintained on a high-

Our results demonstrate a tremendous capacity in this hereditary syndrome to deposit fat without any control. The interaction of the high-fat diet and the ob/ob genotype exerted cumulative effects on the weight of the three fat pads examined, and on the size of fat cells in epididymal adipose tissue. Opposite effects on serum insulin and muscle glycogen were encountered when these two factors were acting muscle [23] are relatively unresponsive to dietary and hormonal manipulation in $\mathrm{O}-\mathrm{H}$ mice. The enlargement of adipose cells and an increased number of mast cells, capable of releasing heparin (a known activator of lipoprotein lipase), might account for the increased weight of epididymal fat pads, without concurrent hyperplasia (Table 2 , and ref. 9).

The contribution of lipogenesis and dietary fat to the glycerides accumulated in $\mathrm{O}-\mathrm{H}$ mice can be estimated approximately from the comparison of the $18: 2$ content in adipose cells and in the diet. On the high-carbohydrate diet, the proportion of $18: 2$ in fat depot corresponded to $45 \%$ of the $18: 2$ content of the vegetable oil present in the diet (Table 3 ). The bodies of these mice probably contained as much as $42 \%$ fatty acids by weight $[4,5,11]$. It is therefore probable that of the $27 \mathrm{~g}$ of fatty acids stored by these $63 \mathrm{~g}$ mice, $12 \mathrm{~g}$ were of dietary origin and $15 \mathrm{~g}$ endogenous. When the same type of mice was maintained on a high-fat diet, the $18: 2$ content of adipose fat was only $19 \%$ lower than that present in lard. This suggests that lipogenesis was responsible for only $20 \%$ of total depot fat. The fat depot of these mice (with a body weight of $94 \mathrm{~g}$ ) amounting to $58 \mathrm{~g}$ [ $27 \mathrm{~g}+(94 \mathrm{~g}-63 \mathrm{~g})]$, was therefore made up of 4 times more exogenous fatty acids $(47 \mathrm{~g})$ than endogenous fatty acids $(11 \mathrm{~g})$. The capacity of fat cells to accept dietary fatty acids was obviously very high. Net lipogenesis was hardly inhibited (one gram less than on the high carbohydrate diet), and still much higher than the total amount of fat deposited in lean littermates submitted to the same $\operatorname{diet}(2.5 \mathrm{~g}$, i.e. $6 \%$ of a total body weight of $41 \mathrm{~g})$ [4].

The lack of depression of lipogenesis in $\mathrm{O}-\mathrm{H}$ mice by dietary fat is in agreement with previous work in vitro [19], but in contrast with data obtained in vivo, where a decreased incorporation of labelled glucose 
into the extrahepatic fatty acids was observed in $\mathrm{O}-\mathrm{H}$ mice given $19 \%$ of lard [11].

The tissues of $\mathrm{O}-\mathrm{H}$ mice were also able to convert into $16: 1$ and $18: 1$ a large proportion of the corresponding saturated fatty acids contained in the lard consumed. This factor demonstrates that the high capacity of this animal to mono-desaturate fatty acids [26] is not limited to the products of lipogenesis and can be extended to dietary fatty acids.

Acknowledgements. This work was supported in part by the financial assistance of the Actions Concertées of the Institut National de la Santé et de la Recherche Médicale (Paris, France) and by contract 1105 of the Fonds de la Recherche Seientifique Médicale (Brussels, Belgium). The authors are indebted to Mrs. Alexiu and MM. Suquet and Hebbelinck for their excellent technical assistance.

\section{References}

1. Best, C.H., Haist, R.E., Ridout, J.H.: Diet and insulin content of pancreas. J. Physiol. (London). 97, $107-119$ (1939).

2. Blázquez, E., Lopez Quijada, C.: The effect of a highfat diet on glucose, insulin sensitivity and plasma insulin in rats. J. Endocr. 42, $489-494$ (1968).

3. Christophe, J., Dagenais, Y., Mayer, J.: Increased circulating insulin-like activity in obese-hyperglycemic mice. Nature 184, 61-62 (1959).

4. - Contribution à la biochimie des obésités expérimentales, p. 1-220, Brussels: Arscia s.a. Ed. (1961).

5. - Jeanrenaud, B., Mayer, J., Renold, A.E.: Metabolism in vitro of adipose tissue in obese-hyperglycemic and goldthioglucose-treated mice. I. Metabolism of glucose. II. Metabolism of pyruvate and acetate. J. biol. Chem. 236, 642-647 and 648-652 (1961).

6. Clément, J., Lemonnier, D.: Composition et structure des triglycérides de réserve du rat blane soumis à des régimes à base de beurre. Nutr. Dieta $8,22-30$ (1966).

7. Fábry, P., Kleinfeld, R., Tepperman, H.M., Tepperman, J.: Effect of diet and insulin on the morphology and TPNH generating enzyme activities of rat adipose tissue. Proc. Soc. exp. Biol. Med. 133, 577-581 (1970).

8. Griglio, S., Goranov, I., Lavau, M., Lowy, R.: Etude des activités enzymatiques du foie et du tissu adipeux épididymaire du rat Wistar $H$ au cours de l'administration à long terme d'un régime hyperlipidique. I. Evolution des activités avec le temps. Enzym. Biol. Clin. 10, 187-208 (1969).

9. Hellman, B.: Studies in obese-hyperglycemic mice. Ann. N. Y. Acad. Sci. 131, $541-558$ (1965).

10. Hirsch, J.: Composition of adipose tissue. In "Adipose tissue as an organ", Kinsell L.W. Ed., p. 79-125, Springfield: Thomas (1962).

11. Jansen, G.R., Zanetti, M.E., Hutchison, C.F. : Studies on lipogenesis in vivo. Fatty acid and cholestorol synthesis in hyperglycaemic-obese mice. Biochem. J. 102, $870-877$ (1967).
12. Lavau, M., Nadeau, M., Griglio, S., de Gasquet, P., Lowy, R.: Métabolisme in vitro du tissu adipeux épididymaire du rat en état d'obésité nutritionnelle. I. Incubations en présence de pyruvate marqué. Bull. Soc. Chim. Biol. 52, 1363-1379 (1970).

13. Lemonnier, D.: Etude de quelques phénomènes physiologiques caractérisant l'obésité nutritionnelle du rat et de la souris. Thèse de Doctorat, 3 me cycle. Paris (1965).

14. - Obésité par des régimes hyperlipidiques chez le rat et la souris. Nutr. Dieta 9, 27-42 (1967).

15. - di Costanzo, P.: Augmentation des stéroides surrénaux chez le rat rendu obèse par un régime hyperlipidique. C.R. Acad. Sc. Paris. 267, 1665-1667 (1968).

16. - Cellularité et caractères morphologiques du tissu adipeux du rat rendu obèse par un régime hyper. lipidique. Arch. Anat. Micr. Morphol. experim. 59, $1-7(1970)$.

17. - Augmentation du nombre et de la taille des cellules adipeuses dans l'obésité nutritionnelle de la souris. Experientia 26, 974-975 (1970).

18. Lipton, J.M.: Effects of high fat diets on caloric intake, body weight, and hoat-escape responses in normal and hyperphagic rats. J. Comp. Physiol. Psychol. 68, 507-515 (1969).

19. Lochaya, S., Leboeuf, N., Mayer, J., Leboeuf, B.: Adipose tissue metabolism of obese mice on standard and high-fat diets. Amor. J. Physiol. 201, 23-26 (1961).

20. Malaisse, W.J., Malaisse-Lagae, F., Wright, P.H.: The effect of fasting upon insulin secretion in the rat. Amer. J. Physiol. 213, 843-848 (1967).

21. - Lemonnier, D., Malaisse-Lagae, F., Mandelbaum, I.M.: Secretion of and sensitivity to insulin in obese rats fed a high-fat diet. Hormone Motabolic Res. 1, $9-13(1969)$.

22. Schemmel, R., Michelsen, O., Tolgay, Z.: Dietary obesity in rats: Influence of diet, weight, age and sex on body composition. Amer. J. Physiol. 216, 373-379 (1969).

23. Stauffacher, W., Crofford, O.B., Jeanrenaud, B., Renold, A.E.: Comparative studies of muscle and adipose tissue metabolism in lean and obese mice. Ann. N. Y. Acad. Sci. 131, 528-540 (1965).

24. Tepperman, H.M., Tepperman, J., Pownall, J., Branch, A.: Effect of saturated fat diets on rat liver NADP-linked enzymes. Amer. J. Physiol. 209, $773-$ $780(1965)$.

25. Westman, S.: Development of the obese-hyperglycaemic syndrome in mice. Diabetologia 4, 141-149 (1968).

26. Winand, J.: Aspects qualitatifs et quantitatifs du mótabolisme lipidique de la souris normale et de la souris congénitalement obèse, p. 1-297, Brussels: Arscia s.a. Ed. (1970).

Dr. D. Lemonnier

Laboratoire de Biologie et de Nutrition Humaine du Conservatoire

National des Arts et Métiers, 292, rue Saint-Martin

F-75 Paris (3e), France 